\title{
Hvaða augum líta börn leikskólakennara? Hlutverk og miðlun gilda í leikskólum
}

\author{
Jóhanna Einarsdóttir og Hrönn Pálmadóttir
}

$\checkmark$ Abstract $\rightarrow$ Um höfundana $\rightarrow$ About the authors $\rightarrow$ Heimildir

Greinin byggir á tveimur rannsóknum par sem leitað var eftir hugmyndum barna um hlutverk og ábyrgð leikskólakennara. Pannig var reynt að skilja pau ómeðvituðu og meðvituðu gildi sem starfsfólk leikskóla miðlar til barna. Byggt er á hugmyndafræði bernskurannsókna par sem litið er svo á að bernskan sé félagslega mótuð og lögð er áhersla á sjónarmið og pátttöku barna. Jafnframt er tekið mið af Samningi Sameinuðu pjóðanna um réttindi barnsins (1992) sem lagði mikilvægan grunn að réttindum og hæfni barna og áhersla er lögð á rétt barna til að tjá skoðanir sínar á málefnum sem varða pau. Markmiðið með greininni er að varpa ljósi á sýn barna á hlutverk fullorðinna í leikskólanum og út frá pví er leitast við að greina pau gildi sem starfsfólkið miðlar til barnanna í daglegu starfi. Niðurstöður rannsóknanna sýndu að í augum barnanna voru hlutverk starfsmanna margpætt og flókin og snerust um að stjórna, veita umhyggju, að veita stuðning og að vera leikfélagi. Dessi fjögur hlutverk voru flokkuð og greind í prjú samofin gildi: Aga, umhyggju og pátttöku. Rannsóknin sýnir hæfni barnanna til að tjá reynslu sína og sjónarmið á fjölbreyttan hátt og mikilvægi pess að starfsfólk leikskóla hlusti á sjónarmið barna í daglegu starfi leikskólans.

Efnisorð: Sjónarmið barna, hlutverk leikskólakennara

\section{Inngangur}

Markmiðið með pessari grein er að varpa ljósi á sýn barna á hlutverk leikskólakennara og annars starfsfólks leikskóla og er hún byggð á tveimur rannsóknum, annars vegar með eins til priggja ára börnum og hins vegar með fimm og sex ára leikskólabörnum (Hrönn Pálmadóttir og Jóhanna Einarsdóttir, 2015; Jóhanna Einarsdóttir, 2014). Leitað var eftir hugmyndum barnanna um hlutverk og ábyrgð leikskólakennara og annars starfsfólks á deildum. ${ }^{1}$ Út frá pví var leitast við að greina pau gildi sem starfsfólkið miðlar til barnanna í daglegu starfi gegnum orð og athafnir. Með pví að skoða hvaða augum börnin líta á skyldur, hlutverk og athafnir starfsfólksins var reynt að skilja pau ómeðvituðu og meðvituðu gildi sem pað miðlar til barnanna.

\section{Bernskurannsóknir}

Rannsóknirnar sem liggja til grundvallar pessari grein byggjast á hugmyndafræði bernskurannsókna par sem leitast er við að skilja bernskuna eins og hún snýr að börnum. Litið er svo á að bernskan sé félagslega mótuð og lögð er áhersla á sjónarmið og pátttöku barna. Bernskurannsóknir hafa próast

\footnotetext{
Í greininni er talað um leikskólakennara og annað starfsfólk á deildum jöfnum höndum. Ekki er gerður greinarmunur á bessum hópum.
} 
á undanförnum áratugum og byggjast pær á trú á styrkleika barna og hæfni til að taka pátt og hafa áhrif á umhverfi sitt. Talað er um börn sem sérfræðinga í eigin lífi og gengið er út frá pví að pau séu fær um að tjá skoðanir sínar og reynslu. Rætt er um rannsóknir með börnum en ekki á börnum og lögð er áhersla á að læra af börnum í stað pess að læra um börn (Dahlberg og Moss, 2005; James og Prout, 1997; Jenks, 2004; Jóhanna Einarsdóttir, 2012; Qvortrup, 1994).

Auk hugmyndafræði bernskurannsókna lagði Samningur Sameinuðu pjóðanna um réttindi barnsins (1992) mikilvægan grunn að réttindum barna til pátttöku í rannsóknum, pó að sáttmálinn fjalli ekki sérstaklega um rannsóknir (Alderson, 2012). Sáttmálinn vakti athygli á samfélagslegri stöðu barna og 1 kjölfar hans urðu málefni barna og réttindi peirra albjóðlega viðurkennd.Áhersla er lögð á virðingu fyrir sjónarmiðum barna og rétti peirra til að tjá sig um málefni sem varða pau. Barnasáttmálinn tekur einnig á rétti barna á vernd fullorðinna fyrir hugsanlegri skaðlegri reynslu. Seinni tíma viðbót við sáttmálann, General Comment No. 7 (United Nations, 2005), beindist sérstaklega að réttindum barna undir átta ára aldri. Rannsóknir með börnum hafa einmitt sýnt fram á hæfni peirra til að eiga samskipti með merkingarbærum hætti frá unga aldri og bent hefur verið á mikilvægi pess að líta einnig til óyrtrar tjáningar pegar leitað er eftir sjónarmiðum ungra barna (Sommer, 2012; Trevarthen og Aitken, 2001). Jafnframt hefur verið bent á að pátttaka barna í leikskólastarfi pýði að börn hafi rétt til að upplifa að afstaða peirra sé virt í daglegu lífi í leikskólanum (Bae, 2009).

Baráttan fyrir réttindum barna og bernskurannsóknir skarast, par sem sýn á börn sem borgara og staða peirra í samfélaginu er í öndvegi. Dessar hugmyndir fela í sér áherslu á börn sem virka borgara með reynslu og skoðanir sem ber að læra af (Alanen, 2011; Kjørholt og Qvortrup, 2012; Quennerstedt og Quennerstedt, 2014).

\section{Gildi og miðlun gilda}

Leikskólar eru mikilvægur vettvangur par sem börn læra um gildi (e. values) í mannlegum samskiptum (Emilson og Johansson, 2009; Hrönn Pálmadóttir og Johansson, 2015). Hér eru gildi skilgreind sem leiðarvísir sem stýrir mannlegu hátterni (Halstead og Taylor, 2000). Litið er svo á að gildi séu samtvinnuð í huga og athöfnum einstaklingsins (Hitlin og Piliavin, 2004). Gildi vísa pví til pess sem kennarar og börn líta á sem eftirsóknarvert í samskiptum, hugsunum, hæfni og reglum.

Með miðlun gilda (e. values education) er átt við starfshætti og aðstæður par sem gert er ráð fyrir að börn læri gildi, sem og reglur, hæfni og venjur sem byggjast á gildum og talin eru mikilvæg í skólasamfélaginu (Halstead og Taylor, 2000; Thornberg, 2008). Miðlun gilda getur verið annars vegar afdráttarlaus, meðvituð og yrt, eins og t.d. í námskrám, og hins vegar ómeðvituð og óyrt, eins og virðist oft vera raunin í leikskólastarfi (Thornberg og Oguz, 2013). Pær athafnir og ákvarðanir sem kennarar taka í daglegu starfi sínu eru byggðar á gildum. Pannig er gildum miðlað gegnum félagslegt, menningarlegt og efnislegt umhverfi leikskólans. Rannsóknir hafa leitt í ljós að gildi eru oftast ómeðvituð og pað er skortur á faglegu tungumáli og pekkingu um pau hjá kennurum. Sjaldan er rætt um gildi og miðlun gilda meðal kennara (Juutinen og Viljamaa, 2016; Thornberg og Oguz, 2013). Í leikskóla móta börn samfélög sín í samskiptum og leik. Í samskiptunum tjá börnin gildi og takast á um pau. Börnin nota flókið samskiptaferli til að tjá eigin sjónarmið og fyrirætlanir og bregðast um leið við sjónarmiðum annarra. Pannig miðla börnin og takast á um gildi sem tengjast pví hvað er gott og slæmt, rétt og rangt í eigin athöfnum og hegðun, sem og félaganna (Hrönn Pálmadóttir, 2017; Johansson, 2011).

Í rannsókn par sem áhersla var lögð á vinnu með gildi í leikskólastarfi kom fram að leikskólakennarar töldu mikilvægt að ræða gildi við börnin og hvetja pau til að reyna að skilja sjónarmið hver annars pegar pau voru studd við lausn ágreinings (Ingibjörg Sigurðardóttir og Jóhanna Einarsdóttir, 2016). Börn tileinka sér pannig pau gildi sem talið er að séu mikilvæg innan veggja leikskólans í fjölbreyttum samskiptum innan félagahópsins og við starfsfólkið. 


\section{Rannsóknarspurningar}

Markmiðið með pessari grein er að varpa ljósi á sýn barna á hlutverk fullorðinna í leikskólanum og út frá pví er leitast við að greina pau gildi sem starfsfólkið miðlar til barnanna í daglegu starfi með orðum sínum og athöfnum. Með pví að skoða hvaða augum börn líta á skyldur, hlutverk og athafnir starfffólksins er reynt að greina pau ómeðvituðu og meðvituðu gildi sem starfsfólkið miðlar til barnanna. Eftirfarandi rannsóknarspurningum verður svarað í pessari grein:

- Hvernig líta börn á hlutverk leikskólakennara og annars starfsfólks í leikskóla?

- Hvaða gildum miðla leikskólakennarar og annað starfffólk í samskiptum sínum við börnin?

\section{Aðferð}

Greinin er byggð á tveimur rannsóknum sem fóru fram með 80 börnum í premur leikskólum í Reykjavík (Hrönn Pálmadóttir og Jóhanna Einarsdóttir, 2015; Jóhanna Einarsdóttir, 2014). Fjórir barnahópar tóku pátt í rannsókninni. Í einum leikskólanum tóku 46 börn á aldrinum eins til priggja ára pátt. Börnin voru á tveimur deildum; önnur var með börn á aldrinum eins til tveggja ára og á hinni deildinni voru börn á aldrinum tveggja til priggja ára. Fjórir til fimm starfsmenn voru venjulega á hvorri deild og gegndu leikskólakennarar stöðu deildarstjóra. Í tveimur leikskólanna tóku 32 fimm og sex ára börn pátt. Á hvorri deild voru venjulega fjórir starfsmenn og voru deildarstjórarnir leikskólakennarar.

Sjónarmið yngstu barnanna (eins til priggja ára) voru að mestu fengin fram með myndbandsupptökum af samskiptum og leik barnanna sem stóðu yfir í fimm mánuði í einum leikskóla. Leikstundirnar sem voru myndaðar fóru fram í tveimur stórum og tveimur minni leikherbergjum eftir morgunmat og vörðu í um pað bil klukkustund. Lítil upptökuvél var notuð til að fylgja börnunum eftir í leiknum. Vettvangsnótur voru ritaðar áður en myndbandsupptökur hófust og einnig samhliða myndbandsupptökunum (Hrönn Pálmadóttir og Jóhanna Einarsdóttir, 2015). Myndbandsupptökurnar voru afritaðar eftir á og greindar. Elstu börnin (fimm til sex ára) fengu einnota myndavélar til umráða og peim var boðið að taka myndir af pví sem pau voru að gera í leikskólanum, bæði af pví sem peim fannst skemmtilegt en líka pví sem peim leiddist. Pau gátu einnig tekið myndir af starfsfólkinu og pví sem pað var að gera í leikskólanum. Eftir að myndirnar höfðu verið framkallaðar voru tekin einstaklingsviðtöl við börnin, pau spurð út í myndirnar og pað sem var á peim. Myndirnar stýrðu viðtölunum. Fáar myndir voru teknar beinlínis af starfsfólkinu svo spurningar um starfsfólkið út frá myndunum voru oft settar fram sem tilgátur. T.d. var spurt: Ef starfsfólkið hefði verið parna hvað myndi pað vera að gera? eða: Hvað var starfffólkið að gera pegar pú tókst pessa mynd? (Jóhanna Einarsdóttir, 2014).

Gagnagreining fór fram í tveimur prepum. Demagreining var notuð við flokkun gagna og til að koma auga á mynstur og pemu innan gagnanna (Braun og Clarke, 2013). Á fyrra prepi greiningar var leitað eftir hugmyndum barnanna um hlutverk og ábyrgð leikskólakennara.Við greiningu var leitast við að kanna og túlka pá merkingu sem börnin lögðu í samskiptin við starfffólk. Síðara prep gagnagreiningar snerist um að kanna hvernig pau hlutverk sem starfsmenn inntu af hendi samkvæmt börnunum endurspegluðu miðlun gilda í leikskólanum. Gildi vísa pví til pess sem kennarar og börn líta á sem eftirsóknarvert í samskiptum, hugsunum, hæfni og reglum.

Kenningarlegt sjónarhorn rannsakanda, sem er háð aðferðafræði, aðferðum og heimspekilegri sýn, hefur áhrif á hvernig börn birtast í rannsóknum (Dockett, Jóhanna Einarsdóttir og Perry, 2011). Hugmyndafræðilegur grunnur og persónuleg reynsla rannsakenda hefur einnig áhrif á pað hvernig gögnin eru túlkuð. Margræðni (e. ambiguity) hlýtur pví ætíð að fylgja pví að kynna sjónarhorn barna og pannig geta rannsakendur aldrei verið fullkomlega vissir um hvernig börn upplifa og tjá reynslu sína. 


\section{Siðferðileg álitamál}

Rannsóknir par sem börn eru pátttakendur krefjast pess að rannsakendur sýni sérstaka aðgát varðandi ýmis aðferðafræðileg og siðferðileg álitaefni, sem varða t.d. rétt barna til friðhelgi og verndar, valdaójafnvægi, upplýst sampykki og trúnað (sjá t.d. Guðrúnu Kristinsdóttur, 2017).

Bent hefur verið á að valdaójafnvæegi milli barna og fullorðinna rannsakenda geti m.a. haft pað í för með sér að börnin leitist við að póknast hinum fullorðna. Aðrir hafa bent á að petta eigi ekki sérstaklega við um börn, par sem fullorðnir hneigist einnig til að gefa pau svör sem rannsakandinn leitar eftir. Leitað hefur verið leiða til að draga úr pessum áhrifum í rannsóknum með börnum, til dæmis með pví að bjóða peim að vera nokkur saman í viðtölum, með pví að gefa peim kost á fjölbreyttum aðferðum og með pví að rannsóknin fari fram á heimavelli barnanna par sem pau eru örugg (Dockett, Jóhanna Einarsdóttir og Perry, 2009; Horgan, 2016; Jóhanna Einarsdóttir, 2007). Í peim rannsóknum sem hér eru til umfjöllunar fór gagnaöflun fram í leikskólum barnanna, par sem pau pekktu sig og voru örugg með sig. Börnin sem tóku pátt voru á mismunandi aldri og voru rannsóknaraðferðirnar valdar með hliðsjón af pví.

Foreldrar allra barnanna sampykktu leyfi fyrir rannsókninni fyrir hönd barna sinna. Upplýst sampykki er ekki síður mikilvægt í rannsóknum með börnum en í öðrum rannsóknum. Pegar leitað er eftir upplýstu sampykki barna er pað ferli sem varir allan pann tíma sem rannsóknin fer fram. Í pví felst ekki eingöngu að veita börnunum upplýsingar í upphafi rannsóknar heldur parf upplýst sampykki að vera til staðar allan tímann. Rannsakendur hafa leitað leiða til að upplýsa börn um hvað pað merkir að taka pátt í rannsókn og sömuleiðis rétt peirra til að hætta við (Dockett, Jóhanna Einarsdóttir og Perry, 2012; Dockett, Perry og Kearney, 2013; Harcourt og Conroy, 2011). Í peim rannsóknum sem hér er greint frá var rannsóknin kynnt eldri börnunum með bví að fara í gegnum bækling með myndum og stuttum texta sem hannaður var með pað í huga að kynna rannsóknina. Rannsakandinn fór í gegnum bæklinginn, útskýrði fyrir börnunum og lét pau vita að pau gætu ráðið hvort pau tækju pátt. Til að leita eftir sampykki yngri barnanna fylgdist rannsakandinn með líkamstjáningu peirra og reyndi að túlka út frá henni hvort pau væru sampykk pátttöku. Í upphafi rannsóknarinnar gáfu sum barnanna til kynna að pau vildu ekki hafa rannsakanda nærri og var pá orðið við óskum peirra. Degar börnin höfðu hins vegar kynnst rannsakanda, sem hafði pá verið í nokkurn tíma á vettvangi, breyttust viðhorf peirra. Petta sýnir að tengsl milli rannsakanda og barna sem eru pátttakendur í rannsókninni eru mikilvægur páttur ferlisins.

Ýmis önnur siðferðileg álitamál í rannsóknum með ungum börnum hafa verið til umfjöllunar. Sem dæmi má nefna rétt barna til friðhelgi, en pví hefur verið velt upp hvort pað sé í págu barna að fullorðnir reyni að komast að bæði stóru og smáu í lífi peirra (Broström, 2006). Hagsmunir rannsakanda annars vegar og barnanna hins vegar geta verið ólíkir ef börn hætta við pátttöku í miðri rannsókn. Баð er mikilvægt að rannsakendur virði tjáningu og rétt barna til pess að hafna pátttöku og taki pann rétt fram yfir eigin rannsóknarhagsmuni.

Á öllum stigum rannsóknar - við val á pátttakendum og aðferðum, við gagnaöflun, greiningu og túlkun gagna - purfa rannsakendur að hafa pað hugfast að raddir barna eru ekki einróma, heldur ávallt félagslegar og háđar félagslegu og menningarlegu umhverfi (Kjørholt, 2008). Bent hefur verið á mikilvægi pess að ná til fjölbreytts hóps barna í rannsóknum til pess að fá fram sem margbreytilegust sjónarmið (Jóhanna Einarsdóttir og Snæfríður Egilson, 2016; Tisdall, 2013; Vandenbroeck og Bouverne-De Bie, 2006). Í peim rannsóknum sem hér eru til umfjöllunar var öllum börnunum á peim deildum leikskólanna sem tóku pátt boðið að vera með í rannsókninni.

\section{Niðurstöður}

Í báđum rannsóknunum birtust samofin pemu sem gáfu innsýn í hugmyndir barnanna um hlutverk leikskólakennara og pau gildi sem miðlað var í leikskólunum. Niðurstöður sýndu að í augum barnanna voru hlutverk starfsmanna margpæett og snerust um a) að stjórna, b) að veita umhyggju, c) að veita stuðning í félagslegum aðstæðum og d) að vera leikfélagi. Dessar niðurstöður eru að mestu 
leyti samhljóða flokkun Anette Koch í rannsókn hennar í dönskum leikskólum, en par komu fram hlutverkin leiðbeinandi, stjórnandi, að veita umhyggju, að veita stuðning og að vera leikfélagi (Koch, 2013, 2016).

Degar skoðuð voru pau gildi sem endurspegluðust í hlutverkum starfsmanna kom í ljós að pau voru samofin í hugum barnanna. Pess vegna voru hlutverkin fjögur flokkuð í prenns konar gildi: Aga, umhyggju og pátttöku. Gildið agi endurspeglar stjórnunarhlutverk leikskólakennara og annarra starfsmanna á deildum par sem reglur eru settar og pess gætt að peim sé fylgt. Gildið umhyggja felur í sér að veita hverju og einu barni stuðning og hlýju og staðfesta færni pess. Gildið pátttaka endurspeglast í hlutverki starfsmanna sem leikfélaga og pátttakenda í samfélagi barnanna.

\section{Agi}

Niðurstöður sýndu að börnin litu á aga sem eitt af megingildunum sem starfsmennirnir tjáđu í samskiptum sínum við pau. Agi felur í sér hlýðni og að aðlaga sig að reglum og skipulagi í leikskólanum (Emilson og Johansson, 2009; Fugelsnes, Röthle og Johansson, 2013). Börnin í öllum leikskólunum virtust hafa reynslu af pví að starfsmennirnir héldu par uppi aga og tækju ákvarðanir. Flest barnanna virtust taka pessum reglum og skipulagi sem aginn fól í sér sem sjálfsögðum hlut. Niðurstöðurnar eru í samræmi við rannsókn á gildum og reglum sem miðlað var í áströlskum leikskóla, par sem börnin virtust ekki draga í efa reglur og skipulag í skólanum (Johansson o.fl., 2014). Í rannsókninni með yngri börnunum kom hins vegar í ljós að sum börn ögruðu reglunum og léku sér til dæmis á svæðum par sem ekki var ætlast til að pau lékju sér. Hér fer á eftir dæmi úr viðtali við Magnús, fimm ára, sem útskýrir hvað starfsmennirnir ákveða og hvað börnin geta haft áhrif á í leikskólanum.

\section{R: Getur pú ákveðið eitthvað í leikskólanum?}

Magnús: Nei. En við getum ákveðið pegar við erum að velja leiksvæði. Pá stjórnum við.

Eins og dæmið sýnir litu mörg eldri barnanna svo á að pau yrðu ekki einungis að laga sig að reglum í leikskólanum heldur gæetu pau einnig haft einhver áhrif. Pau upplifðu að pau væru við stjórn pegar pau gátu ákveðið hvar pau léku sér. Hins vegar voru pað starfsmennirnir sem höfou tekið ákvarðanir um leiksvæðin, fjölda barna á hverju svæði og hvaða leikefni boðið var upp á hverju sinni. Petta hlutverk starfsmanna kom einnig skýrt fram í samskiptum yngri barnanna við starfsmennina. Börnin lærðu pannig af eigin reynslu reglur um hegðun sem giltu í leikskólanum, eins og dæmið hér á eftir sýnir. Gabríel, priggja ára, var að leika sér á gólfinu í einu af litlu leikherbergjunum ásamt nokkrum öðrum börnum:

Gabríel er niðursokkinn við að setja saman lengju úr smágerðum girðingum. Lengjan nær yfir gólfið í herberginu. Hann ýtir henni inn í fremra leikherbergið par sem starfsmaður fylgist með börnunum. Gabríel segir við starfsmanninn: „Sjáðu stóru veiðistöngina mína“ með eftirvæntingu í röddinni. Starfsmaðurinn sampykkir: „Já, hún er stór" með hlutlausum tóni í röddinni og bendir í framhaldi á að pessi leikföng eigi ekki að vera í pessu leikherbergi. Gabríel bakkar inn í litla leikherbergið aftur. Leikfélagar Gabríels höfðu fylgst með samskiptum hans og starfsmannsins af athygli.

Degar Gabríel sýnir veiðistöngina sína virðist tilgangurinn vera að fá viðurkenningu og fá starfsmanninn til að taka pátt í leiknum. Yfirlýsing Gabríels um stærð stangarinnar er staðfest stuttlega en um leið tryggir starfsmaðurinn að reglurnar um hvar leikurinn á að fara fram séu virtar. Gabríel virðir ábendinguna og snýr til baka inn í leikherbergið par sem hann hafði verið áður. Leikfélagarnir fylgdust grannt með samskiptum Gabríels og starfsmannsins. Af ápekkri reynslu læra börn smám saman hvaða reglur gilda í leikskólanum og hvers pau geta vænst af starfsmönnum. Börnin læra til dæmis að pau eiga að leika sér á fyrirfram ákveðnum stöðum og að hlutverk starfsmanna er að stjórna pví án mikillar pátttöku í leik peirra. 
Detta er í samræmi við niðurstöður finnskrar rannsóknar par sem reynsla fimm til sjö ára barna af leikskólavist var könnuð. Börnin töldu að eitt af hlutverkum starfsmanna væri að stjórna fjölda barna á leiksvæðum og hlutast til um samskipti barnanna ef pau væru hávaðasöm eða eirðarlaus (Kyrönlampi-Kylmänen og Määttä, 2011). Áströlsku börnin í rannsókn Johansson og félaga (Johansson o.fl., 2014) tóku pví einnig sem gefnu að kennarar hefðu rétt til að taka ákvarðanir um reglur og pau áttuðu sig á afleiðingum pess að brjóta pær.

\section{Umhyggja}

Umhyggja og tengsl byggð á umhyggju virtust vera lykilgildi í augum barnanna. Рað var mikilvægt fyrir börnin að starfsmennirnir væru tilfinningalega og andlega til staðar og tækju pátt í lífi peirra í leikskólanum. Dví fylgdi einnig að peir sýndu hverju og einu barni umhyggju, staðfestu færni peirra og veittu peim stuðning í samskiptum peirra við félagana. Detta er í samræmi við kenningar Nel Noddings (1992) sem bendir á að umhyggja og að sýna öđrum umhyggiu séu grundvallarparfir manneskjunnar. Petta rímar einnig við norræna stefnumótun í málefnum leikskóla. İ öllum aðalnámskrám norrænna leikskóla er lögð áhersla á umhyggju. Fram kemur að pað sé á ábyrgð fullorðinna að skapa tengsl við börnin sem byggjast á umhyggju. Umhyggja tekur bæði til grundvallarumönnunar og tengsla, sem litið er á sem forsendu vellíðunar, náms og proska barna (Jóhanna Einarsdóttir, Puroila, Johansson, Broström og Emilson, 2015). Dæmið hér á eftir sýnir hvernig umhyggjutengsl birtast í samskiptum eins og hálfs árs drengs, Símonar, og starfsmanns.

Símon situr í háum stól að púsla. Hann hættir og lítur í kringum sig í leikherberginu og kemur auga á starfsmann sem kom inn rétt í pessu. Hann bendir í áttina að honum og kallar: „Ásta“, Ásta kallar til hans á móti „Símon“ með glaðlegri röddu. Símon klifrar niður úr stólnum og gengur til Ástu. Hún tekur hann upp og segir blíðlega: „Komdu hérna, litli minn." Símon brosir.

Darna sýnir Símon ánægju yfir pví að Ásta er mætt og fangar athygli hennar með pví að kalla nafnið hennar. Ásta bregst jákvætt við og sýnir honum umhyggju með pví að taka hann í fangið. Samskiptin milli Símonar og Ástu lýsa gagnkvæmum tengslum milli peirra.

Degar fimm ára börnin voru spurð um hlutverk starfsmanna nefndu mörg peirra mikilvægi samskipta starfsmanna sem byggðust á hlýju og umhyggju, eins og eftirfarandi dæmi sýna:

- Deir hjálpa börnum

- Deir eru góðir við börnin

- Deir hugga börnin

- Deir líta eftir börnum

Dessar niðurstöður eru í samræmi við niðurstöður rannsóknar sem gerð var meðal barna í fyrsta bekk grunnskóla par sem peim var boðið að rekja minningar sínar úr leikskóla. Börnin töluðu ekki mikið um starfsmennina en mörg peirra minntust á starfsmennina pegar pau voru spurð hvenær pau hefðu upplifa sig örugg; pau hefðu verið örugg pegar pau voru nærri starfsmönnum. Pannig virtist umhyggja og stuðningur starfsmanna fléttast saman í huga barnanna og vera mikilvægur páttur í reynslu peirra af leikskólanum (Jóhanna Einarsdóttir, 2011). Niðurstöðurnar eru einnig samhljóða nýlegri rannsókn (Broström, 2016) í Danmörku par sem tíu ára börn ígrunduðu reynslu sína af leikskóla. Minningar barnanna um leikskólann vörðuðu samskipti við félaga og vini og jákvæð samskipti við leikskólakennara. Börnin tjáðu sig ekki um viðfangsefni sem voru skipulögð eða stjórnað af kennurum. Hins vegar kom fram í rannsókn á upplifun barna af grískum leikskólum að börnin lýstu aðallega jákvæðum samskiptum við kennara sína og að gæðin í samskiptunum tengdust pátttöku barnanna í kennarastýrðum verkefnum (Papadopoulou og Gregoriadis, 2016). 


\section{Pátttaka}

Í báđum rannsóknunum lýstu börnin yfir og tjáðu mikilvægi pess að fá viðurkenningu og stuðning frá starfsmönnum. Mikilvægi pess að vera hluti af hópnum og tilheyra samfélagi barnanna kom skýrt fram en jafnframt töldu börnin pað mikilvægt að starfsmennirnir væru pátttakendur í samfélaginu með peim. Börnin lögðu ekki eingöngu áherslu á stuðning heldur einnig á hlutverk starfsmanna sem leikfélaga, en pað er í samræmi við Samning Sameinuðu pjóðanna um réttindi barnsins (1992) og Aðalnámskrá leikskóla (Mennta- og menningarmálaráduneytið, 2011), par sem áhersla er lögð á að gæta jafnvægis milli pess að líta til hæfni og styrkleika barna og pess að börn purfi einnig vernd, leiðsögn og umhyggju.

Gildin pátttaka og umhyggja voru greinilega samtvinnuð í huga barnanna. Pau sóttust oft eftir stuðningi starfsmanna á mismunandi stigum í leiknum. Dannig gáfu pau t.d. til kynna að pau pörfnuðust aðstoðar við að hefja leik, við að halda leiknum áfram pegar hann var að renna út í sandinn, eða pegar átök áttu sér stað í samskiptunum. Starfsmennirnir studdu börnin í leikstundum ef peir litu svo á að pau pyrftu pess með, til dæmis skárust peir í leikinn pegar börnin rifust um leikföng eða byrjuðu leik með yngri börnunum og drógu sig svo í hlé. Viðbrögð og stuðningur starfsmanna var mismunandi og fór eftir börnum. Dæmið hér á eftir sýnir tvö börn; Ísabellu, eins og hálfs árs, og Gísla, tveggja ára, sem sitja saman við hátt borð. Annað barnið óskar eftir stuðningi starfsmanns vegna óviðeigandi hegðunar leikfélagans.

Ísabella er með bát á hjólum og Gísli með strætó. Nokkur smádýr eru líka á borðinu. Börnin ýta leikföngunum fram og til baka og horfa brosandi hvort á annað. Gísli setur eitt dýrið inn í bát Ísabellu, leggst fram á borðið, lítur inn í bátinn og segir: „Halló“ glaðlegri röddu. Ísabella horfir á Gísla og slær hann í andlitið og brosir. Gísli dregur sig til baka, horfir hissa á hana og segir: „Dú mátt ekki gera.“ Hann lítur alvarlegur á svip í áttina til starfsmanns meðan hann nuddar andlitið. Starfsmaðurinn er upptekinn við að aðstoða annað barn og tekur ekki eftir pessu atviki. Gísli hallar sér fram og leggur höfuðið á borðið en Ísabella horfir fram í leikherbergið.

Í dæminu má sjá að Gísli leiðir leikinn við Ísabellu, sem hermir eftir athöfnum hans. Stutta stund ná börnin að skapa sameiginlegan leik með augnsambandi og að ýta farartækjunum fram og til baka. Gísli reynir að bæta við leikinn með pví að setja dýr inn í bátinn hjá Ísabellu. Hún horfir á hann og slær hann en brosir um leið. Gísli dregur sig í hlé og horfir hissa á hana og minnir hana á að petta sé ekki rétt hegðun. Degar hér er komið sögu parfnast Gísli stuðnings og pátttöku starfsmanns og lítur 1 áttina til starfsmannsins, en hann tekur ekki eftir pessu par sem önnur börn kalla á athygli hans. Gísli og Ísabella fengu pví ekki tækifæri til að próa samskipti sín og leik frekar. Detta er í samræmi við niðurstöður Sandberg og Eriksson (2010) sem sýndu að börn pörfnuðust stuðnings kennara í árekstrum sem áttu sér stað í leiknum og að kennarar gátu einnig verið uppbótarleikfélagar ef enginn félagi var til staðar.

Eldri börnin tjáđu einnig pörf fyrir pátttöku starfsmanna í leik. Dæmið hér á eftir sýnir hvernig Atli, fimm ára, bregst við spurningu um hlutverk og verkefni starfsmanna í leikskólanum.Viðhorf hans lýsa ósk um viðurkenningu og pátttöku starfsmanna í leiknum.

- R: Hvað er pað skemmtilegasta sem kennarar gera?

- Atli: Að gera eitthvað með okkur.

- R: Er gaman pegar peir gera eitthvað með ykkur? Leika við ykkur?

- Atli: Já, en pað er ekki oft.

Börnin virtust vilja að starfsmenn væru pátttakendur í samfélagi peirra. Samt sem áður var pað ekki alltaf raunin. Oft voru starfsmenn á hliðarlínunni, fylgdust með börnunum og blönduðu sér aðeins inn í ef einhver óskaði aðstoðar eða að ágreiningur kom upp meðal barnanna. Detta er í samræmi við aðrar norrænar rannsóknir sem gefa til kynna að hefðir leikskólans (e. pedagogical traditions) séu pær að starfsmenn haldi sig í bakgrunni og „bíði og sjái“” hvort stuðnings sé pörf (Jóhanna 
Einarsdóttir, 2005; Kyrönlampi-Kylmänen og Määttä, 2011; Pramling Samuelsson og Johansson, 2009; Sara M. Ólafsdóttir og Jóhanna Einarsdóttir, 2017).

Hér er svo annað dæmi par sem fjögur börn, öll á priðja ári, voru í leik og reyndu að fá starfsmanninn til að taka pátt í leiknum. Börnin voru inni í öðru af stærri leikherbergjunum og völdu að leika á gólfinu með trélestir og lestarteina. Einn starfsmaður var í hvoru leikherbergi. Dæmið sýnir hvernig viðbrögð starfsmannsins geta haft áhrif á próun leiksins.

Lára, Njáll, Rósa og Bergpór eru að setja saman lestarteina pegar Njáll sest allt í einu niður og byrjar að gelta. Lára tekur í peysuna hans og segir „hundur“ með hlýju í málrómnum. Hún gengur um með „hundinn“ og Rósa og Bergpór fylgjast með. Lára og Njáll ganga í áttina að starfsmanninum sem er í hinu leikherberginu. Hún bendir á að „hundakofinn“ sé ekki í pessu herbergi. Börnin snúa til baka en Rósa og Bergpór herma eftir peim. Nú er Bergpór hundur og pau ganga í áttina að sama starfsmanni. Nú bregst starfsmaðurinn við með pví að spyrja börnin hvort pau séu hætt að leika með trélestina og ef svo er pá eigi pau að ganga frá henni í kassann. Börnin hætta í hundaleiknum og byrja að taka lestina saman og raula lágt á meðan „taka lestina saman“.

Í dæminu koma fram ólík sjónarhorn barnanna og starfsmannsins. Tilgangur og löngun barnanna virðist vera að fá starfsmanninn til að taka pátt í leiknum. Önnur hugsanleg skýring á athöfnum peirra gæti verið sú að pau væru að ögra reglum og skipulagi leikstundanna par sem gert var ráð fyrir að pau lékju sér á fyrirfram ákveðnum stöðum eftir að pau höfðu valið sér leikefni. Starfsmaðurinn beinir athygli barnanna að reglunni um pað hvar leikurinn eigi að fara fram. Degar Rósa og Bergpór herma eftir og endurtaka leikinn skömmu síðar gengur starfsmaðurinn skrefi lengra. Hann bendir á að börnin séu ekki að leika „,réttan“ leik par sem pau höfðu valið að leika með trélestina. Rannsóknir sýna að mikilvægur páttur í námi leikskólabarna er að starfsmenn leitist við að nálgast sjónarhorn peirra. Pátttaka starfsmanna byggist pannig á tilfinningalegri nærveru, stuðningi og viðbrögðum sem eru í samræmi við athafnir barnanna (Emilson og Johansson, 2009; Goouch, 2008). Í dæminu virðist starfsmaðurinn ekki hafa petta að leiðarljósi. Samt sem áđur má sjá að börnin virða stjórn og ákvarðanir starfsmannsins og sýna pannig hæfni sína og vilja til samstarfs. Pegar peim er bent á að taka leikföngin saman hefjast pau strax handa við tiltekt og gera pað á leikrænan hátt.

\section{Umræða}

Samkvæmt hugmyndum barnanna voru hlutverk starfsmanna leikskólanna margpætt og flókin og má ætla að pau endurspegli pau gildi sem miðlað var í leikskólunum. Í augum barnanna snerust hlutverkin um stjórnun, umhyggju og stuðning, auk pess sem peim fannst mikilvægt að starfsmenn væru leikfélagar og pátttakendur í samfélagi barnanna. Niðurstöður má flokka í prjú gildi; aga, umhyggju og pátttöku, sem oft birtust samtvinnuð í samskiptum starfsmanna við börnin.

Við fyrstu sýn gæti svo virst sem stjórnunarhlutverkið endurspeglaði ákveðna fjarlægð frá sjónarhorni barnanna, en hin hlutverkin, umhyggja, stuðningur og leikfélagi, endurspegluðu nánari tengsl og pátttöku starfsmanna. Degar betur er að gáð er málið ekki alveg svo einfalt. Hlutverk starfsmanna ráðast ekki eingöngu af gildum og uppeldisfræðilegri pekkingu heldur einnig af menningu leikskólans og skipulagi leikskólastarfsins. Hlutverk starfsmanna eru pannig háð kringumstæðum, tíma dagsins, barnahópnum og peim viðfangsefnum sem unnið er með hverju sinni. Aga, umhyggju og pátttöku er miðlað gegnum pessi hlutverk og pau eru samofin leikskólaumhverfinu.

Aðrar rannsóknir hafa sýnt að ákvarðanir starfsfólks og viðbrögð eru hvorki tæknileg né hlutlaus, heldur tengd gildum pess og sannfæringu (Puroila og Haho, 2017). Uppeldislegur ásetningur verður pó oft að víkja til hliðar vegna stofnanalegra hindrana (Johansson o.fl., 2015). Daglegt starfí leikskóla er pví hád mörgum samverkandi páttum sem hafa áhrif á nám barnanna og möguleika peirra til pátttöku og áhrifa í leikskólastarfinu. 
Frá sjónarhorni barnanna virtust hlutverk starfsmannanna að sumu leyti mótsagnakennd (e. contradictory). Annars vegar var sameiginleg ákvarðanataka takmörkuð og börnin litu svo á að valdið væri í höndum starfsmanna. Flest börnin virtust taka pessu sem sjálfsögðum hlut, virtu stjórnun starfsmanna, sýndu vilja til að vinna saman og að fara eftir reglunum. Pau öxluðu jafnvel ábyrgð og minntu yngri börnin á reglur og ákjósanlega hegðun. Á hinn bóginn virtust börnin líta svo á að starfsmennirnir hefðu ekki mikið frumkvæði, heldur væri hlutverk peirra fólgið í pví að fylgjast með og styðja við börnin, sem gefur til kynna að börnin upplifðu að pau væru sjálf við stjórnvölinn. Рað má velta fyrir sér hvort starfsmenn, meðvitað eða ómeðvitað, ýti undir lýðræði og veiti öllum börnum tækifæri til að próa félagslega færni sína með pví að halda sig til hlés.

Börnin tjáðu einnig andstæð sjónarmið varðandi pátttöku starfsfólksins í leiknum. Annars vegar gáfu pau til kynna að pau ættu sjálf að bera ábyrgð, en um leið kom fram að pau vildu oftar pátttöku starfsmanna en raunin var. Í nýlegri rannsókn par sem sýn barna á hlutverk leikskólakennara í leik var könnuð kom í ljós að staða barnanna í leiknum hafði áhrif á hvernig pau litu á hlutverk kennaranna. Börnin sem höfðu ráðandi stöðu í leiknum litu svo á að pátttaka kennara eyðilegði fremur leikinn á meðan börnin sem voru fylgjendur purftu gjarnan á stuðningi leikskólakennarans að halda og sóttust eftir nærveru hans í leik sínum (Sara M. Ólafsdóttir og Jóhanna Einarsdóttir, 2017). Detta er einnig í samræmi við Ađalnámskrá leikskóla (2011) og Samning Sameinuðu pjóðanna um réttindi barnsins (1992), par sem áhersla er lögð á jafnvægi milli styrkleika barna og færni en jafnframt pörf peirra fyrir vernd og leiðsögn fullorðinna. Í samskiptum barnanna mátti einnig greina núning milli pess að fylgja reglum starfsmanna annars vegar og á hinn bóginn að ögra reglunum og hafa áhrif á umhverfið. Í rannsókn Koch (2013, bls. 18) meðal danskra leikskólabarna kom í ljós að börnin sköpuðu „neðanjarðarlíf“ (e. underground life) sem starfffólk tilheyrði ekki, en um leið voru pau háð hinum fullorðnu. Í neðanjarðarlífi barnanna sköpuðu pau eigin reglur og fengust við viðfangsefni jafnhliða verkefnum sem skipulögð voru af starfsmönnum. Dað er fagleg áskorun að gæta ætíð að réttindum barna og leyfa peim að njóta hæfni sinnar til að hafa áhrif á daglegt líf sitt í leikskóla en gæta um leið að pví að pau eru viðkvæm og háð hinum fullorðnu.

Niðurstöður rannsóknarinnar varpa ljósi á sýn barnanna á pau gildi sem lögð var áhersla á í leikskólunum premur og hvernig pau tókust á við aðstæður par sem gildin stönguðust á. Leikskólabörnin nota gildin; aga, umhyggju og pátttöku, til að kanna réttindi sín og áhrifamátt. Á fyrstu árunum í leikskólanum virtust börnin læra reglur og gildi leikskólans og samsama sig peim, og átta sig um leið á pví hvers pau gætu vænst af starfsmönnunum.

Í rannsókninni kemur glöggt í ljós að börnin tjáđu reynslu sína og sjónarmið á fjölbreyttan hátt, bæði með og án orða. Pau gáfu til kynna að pað væri peim mikilvægt að skapa samfélag í leikskólanum sem byggðist á tengslum og gildum samfélagsins um pað sem er gott og eftirsóknarvert (Halsted og Taylor, 2000; Johansson, 2011). Börnin vildu að starfsmennirnir tilheyrðu samfélagi peirra og að peir tækju til greina sjónarhorn peirra, áhuga og reynslu. Í bernskurannsóknum og hreyfingu um réttindi barna er lögð áhersla á styrkleika og pátttöku barna og hæfni peirra til að greina frá skoðunum sínum og reynslu (Dahlberg og Moss, 2005, James og Prout, 1997; Jenks, 2004; Jóhanna Einarsdóttir, 2012; Qvortrup, 1994; United Nations, 2005). Niðurstöður rannsóknarinnar gefa vísbendingar um hæfni barnanna til að koma sjónarmiðum sínum á framfæri, en jafnframt um pá viðkvæmu stöðu sem pau eru í gagnvart starfsmönnum leikskólans. Рað kom glöggt fram hjá börnunum að pau töldu hlutverk starfsfólks sem leikfélaga og pátttakenda í samfélagi sínu vera afar mikilvægt. Petta kallar á starfshætti sem fela í sér að starfsfólk setji sig í spor barnanna og leitist við að sjá hlutina frá peirra sjónarhóli, en pað er forsenda pess að skapa samstöðu og draga úr valdaójafnvægi milli starfsmanna og barna.

Í leikskólastarfi er mikilvægt að leikskólakennarar og ađrir starfsmenn á deildum átti sig á pví hvernig peir, meðvitað og ómeðvitað, miðla gildum til barna. Dað gera peir með pví að hlusta á hvað börnunum liggur á hjarta og með pví að meta eigin starfshætti. Niðurstöður nýrra rannsókna á gildum í leikskólastarfi varpa ljósi á hvernig starfsfólk getur með fagpróun og ígrundun áttað sig betur á peim gildum sem pað miðlar í starfi sínu með börnum (Ingibjörg Sigurðardóttir og 
Jóhanna Einarsdóttir, 2016; Juutinen og Viljamaa, 2016). Niðurstöður rannsóknarinnar sem hér var til umfjöllunar gefa til kynna að pað sé mikilvægur páttur í starfspróun leikskólakennara að peir ígrundi eigin gildi og starfshætti.

\section{Preschool Teachers in the Eyes of Children: Roles and Values in Preschools}

The aim of the article is to investigate children's views on their preschool educators. It is based on two studies with children aged one to five years old in Icelandic preschools (Hrönn Pálmadóttir \& Jóhanna Einarsdóttir, 2015; Jóhanna Einarsdóttir, 2014). By examining the children's views on the educators' roles, responsibilities, and actions, an attempt was made to understand the conscious and unconscious values that preschool educators communicate to children. The foundations of the two studies are ideas of childhood studies that aim to understand childhood as it is experienced by children, and emphasise the perspectives, agency, and rights of children. Childhood is viewed as a social construction and children are regarded as competent active citizens, capable of participating in and influencing their environment (Dahlberg \& Moss, 2005; James \& Prout, 1997; Jenks, 2004; Jóhanna Einarsdóttir, 2012; Qvortrup, 1994). Childhood studies share intersecting visions and interest with the children's rights movement, which has a base in the UN Convention on the Rights of the Child (United Nations, 2005) ) which recognizes respect for children's views and their rights to express their opinions and influence their environment. Early-childhood education settings are seen as significant places for children to learn values (Emilson \& Johansson, 2009). In this study, values are understood as fundamental principles and convictions which guide behaviour (Halstead \& Taylor, 2000, p. 169). Values education refers to educational practices through which children develop and learn values. Values education can be characterised as either explicit, which refers to embedding teaching values in the official curriculum, or implicit, which refers to communicating values through daily practices in educational settings (Thornberg \& Oguz, 2013). The article aims to answer two questions:

- How do children view the roles of preschool educators?

- What values do preschool educators communicate to children?

Four groups of children in three Icelandic preschools participated in the study. In one of the preschools, 46 children, aged one to three, participated. In two preschools, 32 of the oldest preschool children, aged five to six, participated. The younger children's views were observed mainly through video recordings made during play sessions over a period of five months in one preschool. The older children were given disposable cameras and invited to take photos of what they were doing in preschool. They could also take pictures of the educators and what the educators did in preschool. After the pictures were developed, the children were interviewed individually. Conducting research with children demands attention to several methodological and ethical issues. In this study, the inequality of power between children and the adult researcher was kept in mind; the children were informed of their right to opt out of the study, and when seeking their consent verbal as well as non-verbal gestures were recognized. The findings reveal that according to the children, the roles of the educators were manifold and complex, and it can be assumed that they reflect the values communicated in the preschools. In the eyes of the children, the roles evolved around control, care and support, but the children also found it important that the educators were their playmates and participants in their community. The findings were grouped into three value fields: discipline, care and participation; these were integrated in daily interaction with the children. Discipline stands for the educator's role as controller who sets the rules and makes sure they are followed. The value 
of care involves providing the children with support and the value of participation involves the roles of the educators as playmates and participants in the children's community. The study gives a glimpse of how children express their experiences and perspectives through various means, both non-verbal and verbal. The findings indicate that children are competent to communicate their perspectives, but they are also in a vulnerable position towards the adult educators. The study provides important implications for practice as preschool educators become aware of how they consciously and unconsciously communicate values to children. It is of vital importance that they listen to the children and demonstrate their concern about their acts of meaning, which can provide information about children's perspectives. It is the educators' responsibility to hear what children have to say and to become aware of the explicit and implicit values they are communicating to children.

Key words: Children's perspectives, Preschool, Educators' role, Values, Discipline, Care, Participation

\section{Um höfundana}

Jóhanna Einarsdóttir (joein@hi.is) er prófessor í menntunarfræðum ungra barna við Menntavísindasvið Háskóla Íslands. Hún er einnig heiðursdoktor við Háskólann í Oulu í Finnlandi. Hún hefur stundad rannsóknir í leik- og grunnskólum um árabil og ritað fjölda fræðigreina og bóka um efnið. Sérsvið hennar eru rannsóknir með börnum, samfella í námi barna og starfendarannsóknir. Hún er pátttakandi í alpjóðlegum rannsóknarverkefnum bæði sem rannsakandi og ráðgjafi. Jóhanna situr í stjórn European Early Childhood Education Research Association.

Hrönn Pálmadóttir (hropalm@hi.is) er dósent við Menntavísindasvið Háskóla Íslands. Hún lauk doktorsprófi í menntunarfræði ungra barna frá Háskóla Íslands árið 2015. Helstu áherslusvið í rannsóknum eru samskipti og leikur ungra barna ásamt starfsháttum leikskólakennara.

\section{About the authors}

Jóhanna Einarsdóttir (joein@hi.is) is a Professor of Early Childhood Education at the University of Iceland. She holds an Honorary Doctorate from the University of Oulu in Finland. She has been involved in several international research projects as a researcher and a consultant and published together with international colleagues. Her areas of expertise are educational transitions, children's perspectives and action research. Jóhanna Einarsdóttir is on the EECERA Board of Trustees.

Hrönn Pálmadóttir (hropalm@hi.is) is an associate professor at the School of Education, University of Iceland. She completed her doctoral degree from Iceland University of Education in 2015. Her main research interests include children's interaction and play, as well as preschool teachers' pedagogical approach. 


\section{Heimildir}

Alanen, L. (2011). Editorial: Critical childhood studies? Childhood, 18(2), 147-150. doi: 10.1177/0907568211404511

Alderson, P. (2012). Right-respecting research: A commentary on 'the right to be properly researched: Research with children in a messy, real world'. Children's Geographies, 10(2), 233239. doi: $10.1080 / 14733280903234428$

Bae, B. (2009). Children's right to participate - challenges in everyday interactions. European Early Childhood Education Research Journal, 17(3), 391-406. doi:10.1080/13502930903101594

Braun,V. og Clarke,V. (2013). Successful qualitative research: A practical guide for beginners. London: Sage.

Broström, S. (2006). Children's perspectives on their childhood experiences. Í Jóhanna Einarsdóttir og J.T.Wagner (ritstjórar), Nordic childhoods and early education: Philosophy, research, policy, and practice in Denmark, Finland, Iceland, Norway, and Sweden (bls. 223-256). Connecticut: Information Age.

Broström, S. (2016). Ten-year-olds' reflections on their life in preschool. Nordic Studies in Education, 36(1), 3-19. doi: 10.18261/issn.1891-5949-2016-01-02

Dahlberg, G. og Moss, P. (2005). Ethics and politics in early childhood education. London: Routledge Falmer.

Dockett, S., Jóhanna Einarsdóttir og Perry, B. (2009). Researching with children: Ethical tensions. Journal of Early Childhood Research, 7(3), 283-298. doi:10.1177/1476718X09336971

Dockett, S., Jóhanna Einarsdóttir og Perry, B. (2011). Balancing methodologies and methods in researching with young children. Í D. Hartcourt, B. Perry og T. Waller (ritstjórar), Researching young children's perspectives: Debating the ethics and dilemmas of educational research with children (bls. 68-72). London: Routledge.

Dockett, S., Jóhanna Einarsdóttir og Perry, B. (2012). Young children's decisions about research participation: Opting out. International Journal of Early Years Education, 20(3), 244-256. doi: 10.1080/09669760.2012.715405

Dockett, S., Perry, B. og Kearney, E. (2013). Promoting children's informed assent in research participation. International Journal of Qualitative Studies in Education, 26(7), 802-828. doi:10.108 0/09518398.2012.66289

Emilson, A. og Johansson, E. (2009). The desirable toddler in preschool. Values communicated in teacher and child interaction. I J. B. D. Berthelsen og E. Johansson (ritstjórar), Participatory learning in the early years: Research and pedagogy (bls. 61-77). New York: Routledge, Taylor \& Francis Group.

Fugelsnes, K., Röthle, M. og Johansson, E. (2013). Values at stake in interplay between toddlers and teachers. Í O. F. Lillemyr, S. Dockett og B. Perry (ritstjórar), Varied perspectives on play and learning: Theory and research on early years education (bls. 109-125). Charlotte, NC: Information Age Publishing.

Goouch, K. (2008). Understanding playful pedagogies, play narratives and play spaces. Early Years, 28(1), 93-102.

Guðrún Kristinsdóttir. (2017). Dátttaka barna í vísindarannsóknum. Almenn leiðsögn. Sótt af https:// www.hi.is/sites/default/files/sverrirg/thatttaka_barna_i_rannsoknum.pdf

Halstead, J. M. og Taylor, M. J. (2000). Learning and teaching about values: A review of recent research. Cambridge Journal of Education, 3(2), 169-202.

Harcourt, D. og Conroy, H. (2011). Informed consent. Processes and procedures seeking research partnership with young children. Í D. Harcourt, B. Perry og T. Waller (ritstjórar), Researching young children's perspectives. Debating the ethics and dilemmas of educational research with children (bls. 38-51). London: Routledge.

Hitlin, S. og Piliavin, J. A. (2004). Values: Reviving a dormant concept. Annual Review of Sociology, 91(4), 1499-1528. 
Horgan, D. (2016). Child participatory research methods: Attempts to go 'deeper'. Childhood, 24(2). doi:10.1177/0907568216647787

Hrönn Pálmadóttir. (2017). Gildi í samskiptum og leik ungra leikskólabarna. Sérrit Netlu 2017 Innsýn í leikskólastarf. Sótt af http://netla.hi.is/serrit/2017/innsyn_leikskolastarf/003.pdf

Hrönn Pálmadóttir og Johansson, E. (2015). Young children's communication and expression of values during play sessions in preschool. Early Years: An International Research Journal, 35(3), 289-302. doi:10.1080/09575146.2015.1048429

Hrönn Pálmadóttir og Jóhanna Einarsdóttir. (2015). Young children's views of the role of preschool educators. Early Child Development and Care, 185(9), 1480-1494. doi:10.108 0/03004430.2015.1004056

Ingibjörg Sigurðardóttir og Jóhanna Einarsdóttir. (2016). An action research study in an Icelandic preschool: Developing consensus about values and values education. International Journal of Early Childhood, 48(2), 161-177. doi:10.1007/s13158-016-0161-5

James, A. og Prout, A. (ritstjórar). (1997). Constructing and reconstructing childhood: Contemporary issues in the sociological study of childhood. London: Falmer.

Jenks, C. (2004). Constructing childhood sociologically. Í M. J. Kehily (ritstjóri), An introduction to childhood studies (bls. 77-95). Berkshire, England: Open University Press.

Johansson,E. (2011). Investigating morality in toddler's worlds. Í E.Johansson og J.White (ritstjórar), Educational research with our youngest: Voices of infants and toddlers (bls. 127-140). Dordrecht, Heidelberg, London, New York: Springer Science+Business media.

Johansson, E., Cobb-Moore, C., Ailwood, J., Lunn-Brownlee, J., Walker, S. og Bulton-Lewis, G. (2014). Children's perspectives on values and rules in Australian early education. Australian Journal of Early Childhood, 39(2), 12-20.

Johansson, E., Fugelsnes, K., Ianke Mørkeseth, E., Röthle, M., Tofteland, B. og Zachrisen, B. (2015). Verdipedagogikk i barnehagen. Oslo: Universitetsforlaget.

Jóhanna Einarsdóttir. (2005). We can decide what to play! Children's perception of quality in an Icelandic playschool. Early Education and Development, 16(4), 469-488.

Jóhanna Einarsdóttir. (2007). Research with children: Methodological and ethical challenges. European Early Childhood Education Research Journal, 15(2), 197-211.

Jóhanna Einarsdóttir. (2011). Reconstructing playschool experiences. European Early Childhood Education Research Journal, 19(3), 389-404. doi: 10.1080/1350293X.2011.597970

Jóhanna Einarsdóttir. (2012). Raddir barna í rannsóknum. Í Jóhanna Einarsdóttir og Bryndís Garðarsdóttir (ritstjórar), Raddir barna (bls. 13-27). Reykjavík: Háskólaútgáfan.

Jóhanna Einarsdóttir. (2014). Children's perspectives on the role of preschool teachers. European Early Childhood Education Research Journal, 22(5),679-698. doi:10.1080/1350293X.2014.969087

Jóhanna Einarsdóttir, Puroila, A.-M., Johansson, E., Broström, S. og Emilson, A. (2015). Democracy, caring and competence: Values perspectives in ECEC curricula in the Nordic countries. International Journal of Early Years Education, 23(1), 97-114. doi:10.1080/09669760.2014.970521

Jóhanna Einarsdóttir og Snæfríður Egilson. (2016). Embracing diversity in childhood studies: Methodological and practical considerations. Í A. Farrell og I. Pramling Samuelsson (ritstjórar), Diversity: Intercultural Learning and Teaching in the Early Years (bls. 35-53). Oxford: Oxford University Press.

Juutinen, J. ogViljamaa, E. (2016). A narrative inquiry about values in a Finnish preschool:The case of traffic lights. International Journal of Early Childhood, 48(2), 193-207. doi:10.1007/ s13158016-0165-1

Kjørholt, A.T. (2008). Children as new citizens: In the best interest of the child? Í A. James og A. L. James (ritstjórar), European childhoods: Cultures, politics and childhoods in Europe (bls. 14-37). New York: Palgrave Macmillan. 
Kjørholt, A. T. og Qvortrup, J. (2012). The modern child and the flexible labour market. Early childhood education and care. London: Palgrave Macmillan.

Koch, A. B. (2013). Börns perspektiver på trivsel: Aktivitet og underaktivitet i börnehaven. Nordic Early Childhood Education Research Journal, 6(12), 1-21. doi: 10.7577/nbf.397

Koch, A. B. (2016). Pædagogens rolle og betydning for trivsel i börnehaven. Nordic Studies in Education, 36(3), 193-210.

Kyrönlampi-Kylmänen,T. og Määttä, K. (2011). What do the children really think about a day-care centre. The 5 to 7-year old Finnish children speak out. Early Child Development and Care, 182(5), 505-520. doi: 10.1080/03004430.2011.557861

Mennta- og menningarmálaráđuneytið. (2011). Aðalnámskrá leikskóla. Sótt af http://www. menntamalaraduneyti.is/namskrar/leikskolar/

Noddings, N. (1992). The challenge to care in schools: An alternative approach to education. New York: Teachers College Press.

Papadopoulou,E. og Gregoriadis,A. (2016).Young children's perceptions of the quality of teacherchild interactions and school engagement in Greek kindergartens. Journal of Early Childhood Research, 15(3), 323-335. doi:10.1177/1476718X16656212

Pramling Samuelsson, I., og Johansson, E. (2009). Why do children involve teachers in their play and learning? European Early Childhood Education Research Journal, 17(1), 77-94. doi:10.1080/13502930802689053

Puroila, A. M. og Haho, A. (2017). Moral functioning: Navigating the messy landscape of values in Finnish preschools. Scandinavian Journal of Educational Research, 61(5), 540-554. doi:10.1080/00 313831.2016.1172499

Quennerstedt, A. og Quennerstedt, M. (2014). Researching children's rights in education: Sociology of childhood encountering educational theory. British Journal of Sociology of Education, 35(1), 115-132. doi: 10.1080/01425692.2013.783962

Qvortrup, J. (1994). Childhood matters: An introduction. Í J. Qvortrup, M. Bardy, G. Sgritta og H. Wintersberger (ritstjórar), Childhood matters: Social theory, practice and politics (bls. 1-24). Aldershot: Avebury.

Samningur Sameinuðu pjóðanna um réttindi barnsins. (1992). Sótt af https://www.althingi.is/ lagas/nuna/1992018.2c5.html

Sandberg, A. og Eriksson, A. (2010). Children's participation in preschool - on the conditions of the adults? Preschool staff's concepts of children's participation in preschool everyday life. Early Child Development and Care, 180(5), 619-631. doi: 10.1080/03004430802181759

Sara M. Ólafsdóttir og Jóhanna Einarsdóttir. (2017). „Deir vilja ekki leika, bara tala saman“: Sýn barna á hlutverk fullorðinna í leik. Sérrit Netlu 2017 - Innsýn i leikskólastarf. Sótt af http://netla. hi.is/serrit/2017/innsyn_leikskolastarf/002.pdf

Sommer, D. (2012). A childhood psychology:Young children in changing times. New York, NY: Palgrave Macmillan.

Thornberg, R. (2008). The lack of professional knowledge in values education. Teaching and Teacher Education, 24(7), 1791-1798. doi:10.1016/j.tate.2008.04.004

Thornberg, R. og Oguz, E. (2013). Teachers' view on values education: A qualitative study on Sweden and Turkey. International Journal of Educational Research, 59(1), 49-56. doi: 0.1016/j. ijer.2013.03.005

Tisdall, E. K. M. (2013). The transformation of participation? Exploring the potential of 'Transformative Participation' for theory and practice around children and young people's participation. Global Studies of Childhood, 3(2),183-193.

Trevarthen, C. og Aitken, K. J. (2001). Infant subjectivity: Research, theory, and clinical applications. Journal of Child Psychology, and Psychiatry and Allied Disciplines, 42(1), 3-48. doi: 10.1017/ S0021963001006552 
United Nations. (2005). Convention on the rights of the child: General Comment No. 7. Implementing child rights in early childhood. Genf: Höfundur.

Vandenbroeck, M. og Bouverne-De Bie, M. (2006). Children's agency and educational norms: A tensed negotiation. Childhood, 13(1), 127-143. doi: 10.1177/0907568206059977

Jóhanna Einarsdóttir og Hrönn Pálmadóttir (2019).

Hvaða augum líta börn leikskólakennara? Hlutverk og miðlun gilda í leikskólum. Netla - Veftímarit um uppeldi og menntun. Menntavísindasvið Háskóla Íslands. Sótt af http://netla.hi.is/serrit/2019/menntun_barna_leik_grunn/01.pdf DOI: https://doi.org/10.24270/serritnetla.2019.33 